\title{
Kernos
}

Revue internationale et pluridisciplinaire de religion grecque antique

19 | 2006

Varia

\section{Hera Transformed on Stage}

Aeschylus Fr. 168 Radt

Ioanna L. Hadjicosti

\section{Q OpenEdition \\ 1 Journals}

\section{Electronic version}

URL: https://journals.openedition.org/kernos/461

DOI: $10.4000 /$ kernos.461

ISSN: 2034-7871

\section{Publisher}

Centre international d'étude de la religion grecque antique

\section{Printed version}

Date of publication: 1 January 2006

Number of pages: 291-301

ISSN: 0776-3824

\section{Electronic reference}

Ioanna L. Hadjicosti, "Hera Transformed on Stage”, Kernos [Online], 19| 2006, Online since 24 May

2011, connection on 24 August 2022. URL: http://journals.openedition.org/kernos/461 ; DOI: https:// doi.org/10.4000/kernos.461 


\title{
Hera Transformed on Stage Aeschylus Fr. 168 Radt
}

\begin{abstract}
A fragment of a lost play by Aeschylus (fr. 168) has been paid little attention despite the fact that it presents Hera on stage, and this is something unique in Greek tragedy. This appearance takes place in what seems to be the story of Zeus and Semele and the birth of Dionysus. This text is important for an additional reason; the goddess is transformed into a mortal and this could be the first transformation of a god on stage. The transformation of a god, which is rare in tragedy, could point to the divine transformations found in the Iliad as the source of inspiration for Aeschylus. Furthermore, this hypothesis allows the possibility that this scene became a model for later poets, perhaps Euripides in Bacchae.
\end{abstract}

Résumé : Héra transformée sur scène. Eschyle, fr. 168 Radt. Un fragment d'une pièce perdue d'Eschyle (fr. 168) a peu retenu l'attention alors qu'il présente Héra sur scène, ce qui est unique dans la tragédie grecque. Cette apparition prend place dans ce qui semble être l'histoire de Zeus et de Sémélè, avec la naissance de Dionysos. Ce texte est également important parce que la déesse est transformée en mortelle. Ce pourrait bien être la première transformation d'un dieu sur scène. Une telle transformation est rare dans la tragédie et pourrait indiquer que les transformations divines de l'Iliade ont été une source d'inspiration pour Eschyle. De plus, cette hypothèse ouvre la possibilité que cette scène soit devenue un modèle pour les poètes ultérieurs, peut-être Euripide dans les Bacchantes.

Fr. 168 Radt of Aeschylus has been paid little attention although it presents special interest. Its significance derives from the fact that it presents Hera on stage and this is, as far as we know, unique in Greek tragedy. What is more, Hera is present transformed to a mortal who appears to be gathering offerings for the Muses ( $c f .1 .16-17)$. There are the following questions to be answered in relation to this fragment: which is the tragedy that includes the fragment and what is the role of Hera in the story?

\section{Fr. 168}

4

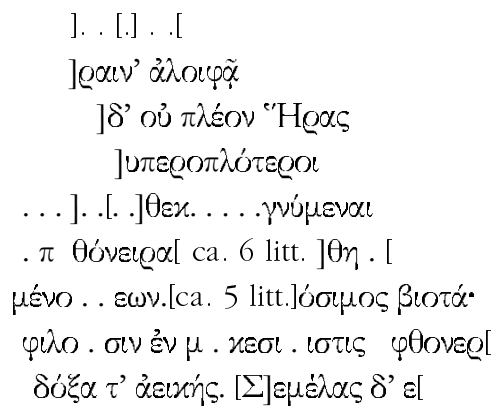


$\chi \alpha^{\prime} \mu \varepsilon \theta^{\prime} \operatorname{siv}^{\top} \nu\llcorner\delta i \alpha \pi \tilde{\alpha} \nu$

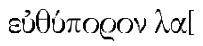

$\tau \dot{\alpha} \gamma \dot{\alpha} \varrho \ddot{\alpha} \lambda \lambda \alpha \tau \dot{\alpha} \delta ’$

$K \dot{\alpha} \delta \mu \omega \sum \varepsilon \mu \dot{\varepsilon}[\lambda \alpha$

.$\pi \alpha \nu \tau O x Q \alpha[\tau$

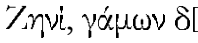

16

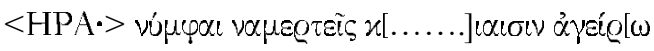

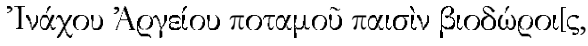

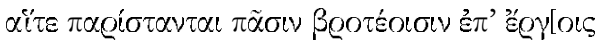

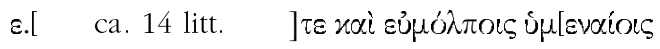

20

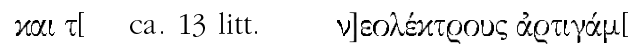

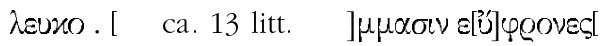

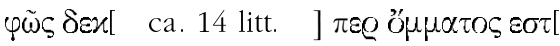

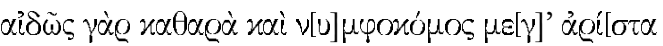

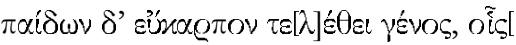

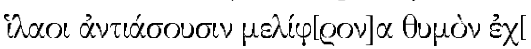

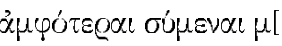

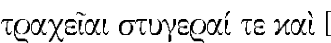

28

$\dot{\alpha}] \gamma \chi \chi^{\prime} \mu \sigma \lambda o \cdot \pi \sigma \lambda \lambda \dot{\alpha} \varsigma \mu \mathrm{ev}[$

.... . ] yov eủvaíou ب̣tòls

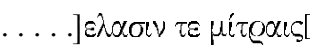

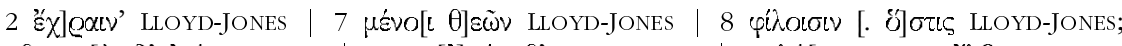

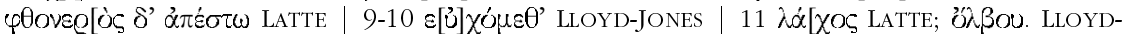

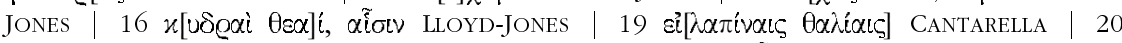

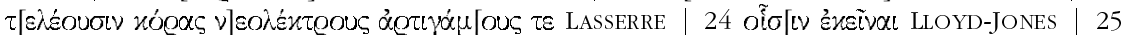

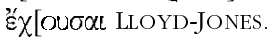

The translation of the fragment reads ${ }^{1}$ :

... anointed with unguents...not more than Hera... more arrogant... mighty... from afar. May there abide...life...the gods... among friendly... But may all the envious be absent, and all unseemly rumour. We pray that Semele's good fortune may ever steer a straight course. For... this other... Semele... Cadmus... the allpowerful Zeus... marriage. [HERA.] Nymphs that speak the truth, honoured goddesses are they for whom I collect offerings, the life-giving children of Inachus the river of Argos. They are present at all the actions of men, at feasts and banquets and the sweet songs of marriage, and they initiate maidens lately wedded and new to love... kindly... eyes... of the eye... For unsullied modesty... is by far the best of adorners for a bride. And fruitful in children are the families of those to whom the nymphs shall come in kindness, with sweet disposition,... coming... both harsh and hateful... when they come near. Many... husband... girdles...

\footnotetext{
${ }^{1}$ The translation is by H. Lloyd-JONES, "Appendix", in H. WeIr-SMYTH, Aeschylus, Cambridge, Mass., Harvard University Press, 1963, pp. 569-71. Note that Lloyd-Jones adopts and translates all the supplements mentioned in the apparatus criticus.
} 
In the first part of fr. 168 (1. 1-15), which is spoken by the chorus, there are clear references to the union of Zeus and Semele ( $c f .1 .9 ; 13 ; 15)$ and in the second part the goddess praises the Muses for their role in wedding and childbirth. The relationship of Zeus and Semele, her pregnancy and the revenge of Hera seem to be the story presented in the lost tragedy that included the fragment. From later testimonies there is evidence for a version of the story of Semele and the birth of Dionysus where Hera was transformed to an old servant of Semele with the objective to destroy both mother and son. This story is attested in Apollodorus, Bibl. III, 4, 3; Ovidius, Met. III, 256315; Hyginus, F., 179 and according to this, Hera was transformed to persuade Semele to ask Zeus for a favour that was to destroy her: to appear to her in full regalia.

In the two latter cases there is the additional detail that Hera took the form of an old nurse of Semele named Beroe. One would have thought that this was the case in the lost Aeschylean tragedy as well, Hera transformed into Beroe, had it not been for two testimonies (Platon, Rep., 381d and Diogenes, Epist. XXXIV, 2) that note that Hera was presented on stage transformed as a priestess. These two testimonies are important because they refer to a theatrical version and moreover because they cite line 17 of fr. 168. They do not, however, mention the tragedy where the line comes from, the context or the playwright. Nevertheless, if these testimonies are connected to the fragment, as this is suggested by the repetition of line 17, then Hera was transformed to a priestess in a lost Aeschylean play that presented the story of Zeus and Semele apparently in an effort to destroy her mortal antagonist and prevent the birth of Dionysus. Before discussing the uniqueness of this presence of Hera, one should identify the play where the fragment comes from.

\section{The Semele / Hydrophoroi}

Originally fr. 168 was assigned to Xantriae of Aeschylus ${ }^{2}$. But the play Xantriae tells the story of Pentheus as in Bacchae of Euripides (cf. Aeschylus fr. 172b and 169) and it is difficult to see how it could accommodate a fragment which is apparently related to the birth of Dionysus by Semele, unless it presented it as past narration. This however cannot be the case: fr. 168 reflects a current situation. This would mean that Xantriae would have to include many independent events, chronologically distant between them, in order to include the fragment: the death of Semele, the birth of Dionysus who was eventually saved by Zeus, his efforts to be established in Thebes against the will of Pentheus after many years, the destruction of the latter and the final prevalence of the god. It is improbable that all this would be presented in a single play. Xantriae was the first choice of the researchers because the scholia on Frogs 1344 cite lines 16-17 of the fragment and assign them to this

\footnotetext{
2 E. LOBEL, "The Xantriae of Aeschylus", P. Oxy. XVIII (1941), p. 27-29; S. RADT, Tragicorum Graecorum Fragmenta, Göttingen, Vandenhoeck \& Ruprecht, 1985, p. $281 \mathrm{ff}$.
} 
play. However, Aeschylus wrote several plays on Dionysus and a less educated scholiast might have had difficulty telling them apart.

There is in fact another play of Aeschylus that could include this fragment: the one preserved with the double title Semele/Hydrophoroi. The play probably presented the story of the birth of Dionysus and the death of his mother and it could accommodate the fragment in question; the chorus of fr. 168 could very well be a chorus of women who carry water, as the second title suggests. This would be in accordance with the hymenaeus that they sing. Nilsson, who agrees with the assignment to Semele, suggests that the female servants are carrying water for the purification bath that is to follow the birth of the child ${ }^{3}$. Taplin and Galiano also agree with the assignment to Semele. Mette and Lloyd-Jones edit the fragment under the title Semele/ Hydrophoroi. There are not many additional testimonies for Semele, however. The fragments traditionally assigned to the play are fr. 221-224, which are of minor importance. The latter three consist each of one word and are simply of lexicographical interest. Fr. 221 allows the possibility that the death of Actaeon was included in the play ${ }^{6}$.

Apart from fr. 168 which is assigned to Semele, perhaps the fragments following it in the Oxyrynchus papyrus (fr. 168a and b) should be assigned to the play as well ${ }^{7}$. Fr. 168a and $\mathrm{b}$ are very lacunose and this does not allow much speculation but they could also be part of the speech of Hera. The word $\mu \dot{\varepsilon} \mu \varphi \rho_{\mu \alpha}$ (168a.2) allows some speculation for criticism, direct or most probably indirect, of what Hera would consider to be the unholy union of Semele with Zeus. Perhaps she talks to the chorus to influence them and suggest the possibility that Semele did not meet the real Zeus, planting the seed of doubt in them. They could transfer this doubt to Semele and lead her to her death. An interesting question is whether Hera would have access to Semele in the play or whether the chorus, or somebody else, would have to act as intermediate. Such intermediates could for example be the sisters of Semele, who doubt her union with Zeus on other occasions ( $c f$. Eur., Bacchai, 26-31). According to a testimony, Semele herself is on stage

${ }^{3}$ M.P. NiLsson, "Sur un drame d'Eschyle et la quête dans le culte grec", AC 24 (1955), p. 340; T. GantZ, "Divine guilt in Aeschylus", CQ 31 (1981), p. 25ff.; F. JouAn, "Dionysos chez Eschyle", Kernos 5 (1992), p. 77; E.R. DoDDs, Euripides: Bacchae, Oxford, Clarendon Press, [1944] 1956, p. 29-30 (intro), who also notes other cases of titles descriptive of the initial situation e.g. Choephoroi, Plyntriae, Ichneutae.

4 O. TAPLIN, The Stagecraft of Aeschylus, Oxford, Clarendon Press, 1977, p. 427-428; M.F. Galiano, "Les papyrus d'Eschyle", in L. Amudsen, V. Skanland (eds.), Proceedings of the IXth International Congress of Papyrology, 1958, Norwegian University Press, 1961, p. 106.

5 H.J. METTE, Der Verlorene Aischylos, Berlin, Akademie Verlag, 1963, p. 141-144; LLOYDJONES, o.c. (n. 1), p. 566-570.

${ }^{6}$ For a discussion on the death of Actaeon as part of the story of Semele in Semele / Hydrophoro $i$ see I.L. HADJICOSTI, "Semele and the death of Actaeon: Aeschylus fr. 221", AClass 49 (2006) forthcoming.

${ }^{7}$ LOBEL, l.c. (n. 2), p. 27-30

${ }^{8}$ As suggested by TAPLin, o.c. (n. 4), p. 427. 
pregnant (schol. Ap. Rhod., I, 636a). To conclude with the play, Semele includes fr. 221-224, 168, perhaps $168 \mathrm{a}, 168 \mathrm{~b}$ and presents the revenge of Hera and her efforts to destroy both mother and child. Semele is killed after she is incited by Hera to ask Zeus to present himself to her in all his power and she is killed by this overwhelming power. Dionysus is saved by Zeus.

\section{The presence of Hera: uniqueness, origin and function}

The presence of Hera on stage is perhaps the most important piece of information concerning this play as far as the presentation of gods on stage is concerned. This happens because Hera, although often playing a part in various myths, is never found on stage in tragedies. For example, in the story of Heracles the intervention of Hera is crucial but at least in Euripides this happens through her agents, Lyssa and Iris. Io in Prometheus is also a victim of Hera but again the goddess does not descend to destroy the mortal herself. In both cases she retains a royal status that allows and perhaps necessitates a more distant approach. Could this reflect some kind of hesitation on the part of poets to bring Hera on stage because of the status she has to retain? Easterling, who sees no hesitation to present gods on stage in Greek drama, notes that there is prohibition as far as Zeus is concerned. Zeus is never present on stage. The testimony of Pollux, IV, 130 for his presence in the lost Psychostasia of Aeschylus is not convincing, at least not for the original performance $^{10}$. This would have been the case for Hera as well had it not been for fr. 168 in a lost play of Aeschylus where Hera is present transformed $^{11}$.

To understand the uniqueness of this presentation of Hera one should have a look at epiphanies in tragedy. There are many such cases as it is clear from the surviving plays and occasionally from testimonies for lost plays but Hera, as Zeus, is never present. It is, moreover, a fact that in all cases of epiphany whether the god makes a distant appearance from the theologeion or ex machina, or whether $\mathrm{s} /$ he is actively engaged in the plot, $\mathrm{s} / \mathrm{he}$ always appears in her/his true shape and never in disguise or transformed. There is, of course, one exception that will be discussed later on: Dionysus in Bacchae. For example, there are several epiphanies in the corpus of Aeschylus: in Oresteia gods are on stage as characters of action; Athena and Apollo, appear in their true shape and they interfere with mortals throughout the trilogy. In the lost Aeschylus there are more cases of the presence of gods on stage; Thetis and her sisters in Hoplon Krisis are probably present for the judgment of weapons ( $c f$. Aes., fr. 174 and schol. Ar., Ach., 883), and they are also

\footnotetext{
9 P. EASTERling, "Gods on stage in Greek tragedy", in J. DALFEN, G. PeTERSMann, F.F. SCHWARTZ (eds.), Religio Graeco-Romana, Horn, 1993, p. 78-79, who suggests that the mask convention is an additional reason to allow the presentation of gods on stage in drama, notes, however, the prohibition of poets to present Zeus on stage.

${ }^{10}$ TAPLin, o.c. (n. 4), p. 431ff.; EASTERLing, l.c. (n. 9), p. 79.

${ }^{11}$ Transformation is a more appropriate word in this case than the word disguise according to the two testimonies. See TAPLIN, o.c. (n. 4), p. 428.
} 
present in Nereids, as is indicated by the title, a play that is probably on the death of Patroclus and the laments that followed as well as the preparation of Achilles for his battle with Hector ( $c f$. Aes., fr. 150-154). Lyssa is present in Xantriae (Aes., fr. 169) to madden the women. Hermes comes to bring a message to Achilles at the beginning of Phryges / Hektoros Lytra (cf. schol. Ar., Frogs, 911). In Danaides Aphrodite is present (Aes., fr. 44). In Prometheus there are several gods on stage as it is a play primarily concerned with divine characters; Bia, Kratos, Prometheus and Hermes are all characters of action ${ }^{12}$. In the surviving Sophocles we have Athena in the prologue of Ajax and Heracles at the end of Philoctetes who comes to resolve the play (1. 1409ff.). There is an interesting case of epiphany in the lost plays of Sophocles that should also be mentioned; Apollo and Artemis in Niobe are present on stage killing the female children of Niobe with extreme cruelty ( $c f$. Soph., fr. 441a).

In Euripides there are many epiphanies; Athena in Supplices, comes from above the stage to resolve the play (1. 1183ff.), Dioscouroi, as gods ex machina, appear both in Helen and in Electra (1. 1238ff.). In Hippolytus Aphrodite speaks the prologue and Artemis appears on the theologeion at the end of the play (1. 1439ff.). In IT Athena comes as the deus ex machina (1. 1435ff.). In Ion Hermes speaks the prologue and Athena once more is in the role of the deus ex machina. In Orestes Apollo is the deus ex machina. In Heracles Iris and Lyssa appear above the house and cause the madness of the hero, under the instructions of Hera (1. 822ff.; 831; 840; 855; 857; 859). In Trojan Women Poseidon and Athena speak the prologue and present the situation to the audience. Apollo is present in the prologue of Alcestis with Thanatos. Thetis in Andromache comes to lament her grandson at the end of the play (1. 1231ff.). In the spurious Rhesus Athena comes ex machina (1. 595ff.) to speak to Odysseus who recognizes her voice and the Muse comes later, once more from above, to lament her son and carry him away (1. 890ff.) $)^{13}$.

Lastly, there is the case of Dionysus in Bacchae. This is a unique case in surviving tragedy because there is a crucial difference between this and all other epiphanies; in Bacchae Dionysus appears transformed so as not to be recognized by the other characters of action. On the contrary, the audience knows the truth because the god reveals it in the prologue (1. 4; 53). Dionysus is clearly transformed into a mortal man, although no further definition is offered, and not disguised. This would have been the only attested case of divine transformation in Greek tragedy had it not been for what we believe to be the lost Semele / Hydrophoroi of Aeschylus. Furthermore, the latter could in fact be the first attested case of divine transformation on stage; no doubt

\footnotetext{
12 See the discussion on the authenticity in M. GRIFFITH, The Authenticity of the Prometheus Bound, Cambridge, University Press, 1977.

13 Note that the authenticity of Rhesus is problematic. See discussions in G. BJORCK, "The authenticity of Rhesus", Eranos 55 (1957), p. 7-17; W.H. PORTER, The Rhesus of Euripides, Cambridge, University Press, 1916; W. RITCHIE, The authenticity of the Rhesus of Euripides, Cambridge, University Press, 1964.
} 
Semele predated Bacchae $e^{14}$. In both cases the gods perform a more devious task than the usual divine tasks. They transform to manipulate mortals, to cause them to bring themselves the destruction upon them. Dionysus is a lesser god than Hera is and as such he has more freedom to do things than she has. In other words, it is more acceptable for him to misbehave. On the other hand, Hera is an honourable and important goddess and this presentation of her as a devious transformed priestess comes as a surprise.

One should examine the origin of this presentation of Hera as a goddess so scheming that transforms to destroy her enemies in tragedy. Does this strange appearance of Hera have its roots in earlier tradition? In Lyric poetry and in Hesiod there are no traces in what survives for a transformation of Hera although there are cases attested where she has strong hostile feelings against the illegitimate children of Zeus and the action she takes against them frequently involves deception. In Hesiod there are references to her hatred towards another one of Zeus' illegitimate children, Heracles (fr. 25, 30; 229, 10). In the epic cycle we meet Hera in the Cypria. According to the summary by Proclus (1. 4ff.) for the Cypria, Hera descends from Olympus for the judgment of Paris but it seems that this is done without any sort of transformation; besides Paris would have to judge her physical beauty against that of Athena and Aphrodite. More importantly, Hera has a strong presence in the Iliad. There she is characterized by two things; her lust for vengeance, which is determining in the last books of $\mathrm{Iliad}^{15}$, and her ability to deceive. Her deception is mainly directed against Zeus and not mortals, although it is meant to cause some kind of disaster to mortals. Two occasions where she used dolos in the past are mentioned in the poem; the first is when she used Hypnos to put Zeus to sleep in order to blow Heracles off-course on his return from Ilion (XIV, 229ff.; 15, 31ff.). The second occasion is found in a speech by Agamemnon; this is another occasion when Hera deceived Zeus with the objective of creating a life of toil for Heracles (XIX, 96ff.). It is noteworthy that both these cases are related to the same hero. Additionally, in

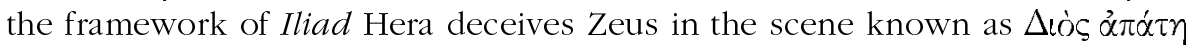
of Book XIV in order to press the Trojan army.

Although Hera's deception in Iliad is not combined with transformation of any kind there are, nevertheless, several cases in the poem where other gods take on mortal shape to achieve their goals; often this is to deceive. Some times the gods take the shape of a mortal familiar to the one that they are about to deceive in order to gain his trust. Athena does this twice: in book IV 86ff. she is changed into Laodokos in order to persuade Pandaros to break the truce between the two armies and in XXII 226ff. she is changed into Deiphobos, the brother of Hector, to persuade the latter to stop running away

\footnotetext{
${ }^{14}$ Mortals can also be transformed in tragedy so as not to be recognized when needed, as Odysseus is attested to be in the Philoctetes of Euripides (Dion, LII, 5; LIX, 3).

15 J. O'BRIEN, The Transformation of Hera, Lanhman, Rowman and Littlefield, 1993, p. 77.
} 
and face Achilles, thus leading the Trojan prince to his death ${ }^{16}$. Moreover, Poseidon is transformed to a mortal while he engages in mortal fighting in XIII, 357ff., in order to escape detection by his brother Zeus. Hera spots him straightaway (XIV, 153ff.), however ${ }^{17}$. Apollo is transformed to Agenor in XXI. 600ff., in order to deceive Achilles and save the real Agenor, who is about to be killed by the hero. Hermes in XXIV, 182ff. is transformed in order to serve as guide to Priam who enters the enemy camp for the ransoming of Hector.

Although Hera herself is not transformed in Iliad, her transformation in fr. 168 reminds those of Iliad. The fact that Hera is transformed with bad intentions for Semele resembles the transformations of Athena in Iliad IV and XXII more than any other Iliadic transformation. The goddess in this case does not destroy the mortal herself; she descends transformed to persuade the mortal to do something that will have bad consequences; in the case of Pandaros and Semele the goddesses cause them to sin, and as with Semele so with Hector this leads the mortal to death. The transformations of Apollo, Hermes and Poseidon in Iliad are all different. It is only Athena who transforms to cause somebody to do a fatal mistake. This is exactly what the function of Hera seems to be in Semele; she causes the heroine to commit hybris by inciting her to ask Zeus for something which is prohibited to mortals ( $c f$. fr. 154a.15-6). This is in a way similar to what Clytaemnestra, a mortal this time, does in the carpet scene of Agamemnon; she causes the king to commit hybris by provoking him to step on the red carpet of vanity.

It is plausible that Aeschylus would turn for inspiration for this metamorphosis to Iliad. But this does not explain the reason for including this metamorphosis in his story. Why is Hera exceptionally, as far as we know, brought on the Aeschylean stage and, even more exceptionally, transformed? Her physical presence would apparently imply her strong feelings against Semele, so strong that perhaps necessitated a personal punishment. But how to explain the transformation? If Hera wanted to destroy Semele in a direct way, she would not have to conceal herself. She would either appear to speak the prologue explaining why and how the destruction of Semele would occur or she could appear at the end of the play to take responsibility and express her satisfaction for the punishment. She could alternatively not appear at all and send agents, e.g. Iris and Lyssa (cf. Eur., Her.). Or we could have a combination of both her, to pronounce the punishment, and her agents, to enact it. But Aeschylus apparently does not want a direct punishment. He

\footnotetext{
${ }^{16}$ In the Odyssey Athena is transformed twice to take the form of Mentor (II, 267ff.; XXII, 205ff.) to help Telemachus and Odysseus respectively. She even takes Telemachus' form for a short while (II 383ff.) to gather men for the voyage to Pylos and then she transforms into Mentor's form again (II 401). But in the cases mentioned here she takes the form of a friend to help and not to deceive the mortal. In Odyssey Athena also transforms Odysseus with her magic wand (XIII, 429; XVI, 173; XVI, 456).

17 T.R.M.E. NELSON, "Deception, gods and goddesses in Homer's Iliad", AAntHung 37 (1996/7), p. 194, suggests that by doing this Poseidon only wanted to avoid detection for as long as possible.
} 
prefers to have the goddess on stage in this deceitful role and to create in this way a complex destruction of Semele; Hera is to persuade Semele to cause her own death through an act of hybris. Her plan in this play is Machiavellian; Zeus will technically destroy Semele after her pleas to see him in all his majesty, as Hera had seen him. The girl demands what the greatest of the goddesses has: the opportunity to see Zeus with full powers. Zeus is forced by a promise to comply. Semele, therefore, causes her own destruction as she cannot possibly survive what she asks for. Hera only gives food to her vanity. We should, nevertheless, allow another possibility for the transformation of Hera; that Aeschylus could not present her on stage in her natural form, as he probably could not present Zeus. Perhaps she was too important and too respected to risk presenting her in all her glory.

To what extent this version was new when Aeschylus used it in the Semele is not clear. As noted above, there are some later references to a version where Hera persuaded Semele to request such a favour from Zeus but twice this is connected with her transformation to Beroe, the nurse of Semele (Ovid., Met. III, 256-315; Hyg., F., 179). Although the references are later than Aeschylus, they could in fact depict older tradition. There might in fact have been two similar versions at the time of Aeschylus with Hera as a nurse and as a priestess. The former is in fact closer to what Athena does twice in Iliad; she transforms to a friend of the mortal that she wants to destroy and leads the latter to his destruction. The case of the priestess is slightly different; she would not be as close to Semele but she would be a respectable figure whose words would carry some weight. It is not a coincidence that Hera in the surviving fragment speaks/sings a monody in lyric hexameters, a metre that has a more elevated tone ${ }^{18}$. Taplin considers this to be a monody entry and sees the choice of the metre as the result of her transformation and suspects some special dramatic purpose ${ }^{19}$. Perhaps this purpose was to add gravity to her words and give her authority.

It is important, however, to note that Aeschylus either chose the version with the priestess over that with the nurse or, more interestingly, he created it. The latter is not improbable. In any case, Aeschylus presented Hera on stage transformed and by doing so he created a tragedy where there are no victims. A direct attack would probably leave Semele as the victim. The transformation and deceit of Hera, on the contrary, makes her responsible for her death through her hybris. Zeus is put in a complex situation, as well. He kills Semele, entrapped by a promise that he would do anything for her, even when he knows that what she asks for will bring her death.

A further question is how would the transformation of Hera work practically in the course of the play? Would Hera come before the parodos to reveal to the audience her true identity? The audience has to be able to understand

\footnotetext{
${ }^{18}$ M.L. WEST, Greek Metre, Oxford, Clarendon Press, 1982, p. 35-98, notes that hexameters are occasionally used in tragedy as the metre of wisdom $e . g$. in oracles and riddles and have a more elevated tone (cf. Sophocles, Philoctetes, 839-843).

${ }^{19}$ TAPLIN, o.c. (n. 4), p. 427
} 
the plot and to do so, as in the case of Dionysus in Bacchae, they need to know the real identity of the priestess. If so, then this must be done before the entrance of the chorus, which consists of women servants of Semele, apparently faithful to their mistress ${ }^{20}$. Unless one allows what seems to be a faint possibility: that the chorus left the stage at some point of the drama. Although this happens in some cases, it seems implausible to suggest this for Semele with no further evidence ${ }^{21}$. Would Hera then appear alone in the prologue and like Dionysus explain the truth to the audience? Without forgetting the lack of evidence for a large proportion of the Aeschylean corpus, one should note that prologues spoken by one person are not usual in surviving Aeschylus ${ }^{22}$. Hera could come with one of her followers to whom she would explain her plan. This could, for example, be Lyssa or Iris.

Would the transformed Hera reveal herself at some point of the drama and appear in her true nature? It is noteworthy that in most cases in Iliad after the transformation comes the revelation. Hermes reveals himself to Priam (XXIV, 460ff.), Apollo reveals himself to Achilles (XXII, 7ff.) and Hector is allowed to realize that is was Athena and not his brother who persuaded him to confront Achilles (XXII, 296ff.) ${ }^{23}$. Dionysus also reveals himself at the end of Bacchae: he comes ex machina (1. 1330ff.) and identifies himself (1. 1340-1341). Again there is the question of whether Aeschylus would want to risk presenting the goddess in her true shape. If not, then she could send an agent to do this after her plan met with success or she could simply allow the chorus or the characters to understand the truth. Besides, there would apparently be a messenger speech where the death of Semele would be narrated as well as the miraculous salvation of Dionysus by Zeus. If so, then both the role of Hera and Zeus in the story could have been clarified off stage and simply reported on stage. An additional question that should be discussed is how the audience would receive the presence and conduct of Hera in Semele. Hera comes at a happy context and encounters the female chorus who prepare the purification water for bathing Dionysus in joy, and creates chaos. She kills the pregnant mother and almost kills the unborn child. Would this shock the audience or would they feel that Hera was in a way justified to act as she did? Would they feel that Semele brought this to herself? Even so, it is difficult to see how the cruelty of Hera and the near death of both mother and child might not have sounded cruel.

The transformation of Hera is in fact criticized at least once in antiquity. This is done by Platon, Rep., 381d and conceivably his criticism implies both her presence and her subsequent deceitful conduct. It is not the first time that

\footnotetext{
${ }^{20}$ TAPLin, O.C. (n. 4), p. 428

${ }^{21}$ This is the case e.g. with A., Supplices, 231; S., Ajax, 814; E., Helen, 385 and E., Alcestis, 747; the chorus leaves the stage to return later. See discussion in J.C. KAMERBEEK, The Plays of Sophocles Ajax, vol. 1, p. 167.

22 M.L. WEST, "Iliad and Aethiopis on stage: Aeschylus and son", CQ 50 (2000), p. 349.

23 Pandaros does not learn the truth but he is such a minor figure that perhaps the poet cannot afford further elaboration. He is simply used to achieve the breaking of the truce.
} 
Platon criticizes the way in which some gods are presented by Aeschylus. He also criticizes the conduct of Thetis in fr. 350 (cf. Rep., 383a), when she reproaches Apollo for lying to her when prophesying longevity for Achilles at her wedding and then killing her son at Troy. Apparently, Aeschylus occasionally allows gods to be deceitful ( $c f$. Aes., fr. 301). As suggested by Gantz, who gives the example of fr. 350 with Thetis and Apollo and of the lost play of Aeschylus Niobe, where the children of the heroine are killed by Artemis and Apollo ( $c f$. fr. 154a-167b), the playwright often presents gods in "situations that invite judgment", but only to achieve by the end of the play or of the trilogy some kind of reconciliation ${ }^{24}$. It is true that at least temporarily the poet puts certain gods in a position that invites judgment but would he always work his way towards reconciliation? It is not necessary that he would do so; in tradition there is no reconciliation attested between Hera and Dionysus or Heracles, her traditional enemies.

To conclude, the on stage presence of Hera in fr. 168 is unique in tragedy and it is moreover the first, as far as we know, divine transformation on stage. The transformation points to Iliad as the source of Aeschylus' inspiration, especially to the transformations of Athena there. Hera's physical presence and her conduct would probably make an impression on the audience. Some would perhaps consider it improper, as Platon does. In any case, the Euripidean Dionysus of Bacchae had at least one precedent, as far as his transformation is concerned, the presentation of Hera in Semele/Hydrophoroi. Interestingly, both transformations are related one way or another to the myth of Dionysus.

Ioanna L. HADJICOSTI

University College London

E-mail: bcioannal@botmail.com

${ }^{24}$ GANTZ, l.c. (n. 3), p. 29-32. 